Tropical Journal of Pharmaceutical Research March 2019; 18 (3): 597-602

ISSN: $1596-5996$ (print); 1596-9827 (electronic)

(C) Pharmacotherapy Group, Faculty of Pharmacy, University of Benin, Benin City, 300001 Nigeria.

\title{
Antidiabetic effect of hydro-methanol extract of Prunus cerasus $L$ fruits and identification of its bioactive compounds
}

\author{
Gong Xiao, Xiangcheng Xiao* \\ Department of Nephrology, Xiangya Hospital, Central South University, Changsha, Hunan 410008, China
}

${ }^{*}$ For correspondence: Email: BicklerElese@yahoo.com; Tel: 0086-13787312910

Sent for review: 17 November 2018

Revised accepted: 19 February 2019

\begin{abstract}
Purpose: To investigate the antidiabetic effect of hydro-methanol extract of Prunus cerasus fruit extract. Methods: The antidiabetic activity was assessed in alloxan-induced diabetic rats. The effect of $P$. cerasus fruit extract on plasma fasting blood glucose (FBG), insulin, C-peptide, total protein, glycosylated hemoglobin (HbA1c), total hemoglobin, reduced glutathione (GSH), vitamins $E$ and $C$, ceruloplasmin, lipid profile, histology of the pancreas, and expression of glucose transporter type 4 (GLUT-4) were determined using standard procedures. Liquid chromatography-mass spectrometry was used for phytochemical analysis.

Results: Alloxan-induced diabetes significantly reduced plasma levels of insulin, $C$-peptide, total hemoglobin and total protein, and significantly increased FBG and HbA1c levels $(p<0.05)$. However, after treatment with the extract, changes in the levels of these parameters were significantly and dosedependently reversed ( $p<0.05)$. The extract also increased the levels of $G S H$, vitamins $E$ and $C$, and. Alloxan-induced DM significantly increased the levels of triacylglycerols (TGs), low-density lipoprotein cholesterol (LDL-C) and high-density lipoprotein cholesterol (HDL-C), and significantly reduced the level of total cholesterol (TC) at different time points $(p<0.05)$. However, after treatment, the levels of TG, $L D L-C$ and HDL-C declined but TC level was significantly elevated time- and dose-dependently by the extract $(p<0.05)$. The extract upregulated the expression of GLUT-4 mRNA in soleus muscle and adipose tissue. LC-MS analysis revealed that the extract contained chlorogenic acid, rutin, diadzin, amygdalin, quercetin and naringenin.

Conclusion: The results obtained in this study have shown that hydromethanol extract of $P$. cerasus fruits exhibits remarkable antidiabetic effects.
\end{abstract}

Keywords: Prunus cerasus, Diabetes mellitus, Alloxan, Fasting blood glucose, Oxidative stress

This is an Open Access article that uses a funding model which does not charge readers or their institutions for access and distributed under the terms of the Creative Commons Attribution License (http://creativecommons.org/licenses/by/4.0) and the Budapest Open Access Initiative (http://www.budapestopenaccessinitiative.org/read), which permit unrestricted use, distribution, and reproduction in any medium, provided the original work is properly credited.

Tropical Journal of Pharmaceutical Research is indexed by Science Citation Index (SciSearch), Scopus, International Pharmaceutical Abstract, Chemical Abstracts, Embase, Index Copernicus, EBSCO, African Index Medicus, JournalSeek, Journal Citation Reports/Science Edition, Directory of Open Access Journals (DOAJ), African Journal Online, Bioline International, Open-J-Gate and Pharmacy Abstracts

\section{INTRODUCTION}

Prunus cerasus belongs to the Rosaceae family and it is locally known as sour cherry. Its fruits are rich in nutrients and a number of bioactive compounds such as polyphenols and flavonoids [1]. Studies have shown that plant materials rich in natural antioxidants such as flavonoids and phenolics lower the risk of cardiovascular disease (CVD), neurodegenerative disorders, 
oxidative stress, cancer, and Diabetes mellitus (DM) [2].The antioxidant and anti-inflammatory properties of extracts of $P$. cerasus have been attributed to the presence of polyphenols in the plant [3].Metabolic disorders and oxidative stress play key roles in the pathogenesis of DM [4].Type 1DM (TIDM) is due to insulin deficiency, while type 2 DM (T2DM) is caused by insulin resistance.

Plant extracts rich in antioxidant molecules have been shown to be beneficial in the treatment of DM $[5,6]$. At present, studies on the antidiabetic properties of extracts of $P$. cerasus are scanty. The aim of this study was to investigate the antidiabetic effect of hydro-methanol extract of $P$. cerasus fruits and its bioactive components.

\section{EXPERIMENTAL}

\section{Collection and extraction of $P$. cerasus fruits}

Fresh fruits of $P$. cerasus were collected from the wild and identified at the Department of Botany, Central South University, Changsha, Hunan, China. A voucher specimen was prepared and kept at the herbarium of the department. The fruits were dried in an incubator for 2 days at $40^{\circ} \mathrm{C}$, crushed separately in an electric grinder, and then pulverized.

A portion of the powder $(50 \mathrm{~g})$ was dissolved in a $2: 3$ volume ratio of water and methanol $(100 \mathrm{ml}$ water and $150 \mathrm{ml}$ methanol) and kept in the incubator at $37^{\circ} \mathrm{C}$ for $36 \mathrm{~h}$. The slurry was stirred intermittently at intervals of $2 \mathrm{~h}$, and left overnight. The mixture was thereafter filtered and the filtrate concentrated using a vacuum rotatory evaporator. The resultant concentrate was freeze-dried by lyophilization.

\section{Liquid chromatography-mass spectrometry (LC-MS)}

A portion of the dried hydro-methanol extract $(9 \mathrm{~g})$ was subjected to LC-MS for characterization as described previously [7].

\section{Acute toxicity study of hydro-methanol extract of $P$. cerasus fruits}

This was performed according to Lorke's method.

\section{Induction of DM and grouping of experimental rats}

Twenty five adult male Wistar rats weighing 170.0 to $190.0 \mathrm{~g}$ (mean weight $=180.0 \pm 5.80 \mathrm{~g}$ ) were randomly assigned to five groups of five rats each: normal control group, extract control group, diabetic control group and two treatment groups. With the exception of normal control and extract control groups, DM was experimentally induced in the rats by intravenous injection of alloxan $(150 \mathrm{mg} / \mathrm{kg}$ bwt). After $72 \mathrm{~h}$, rats with plasma glucose levels $>200 \mathrm{mg} / \mathrm{dL}$ were classified as diabetic. The diabetic control group was not treated, while the treatment groups received 100 or $200 \mathrm{mg} / \mathrm{kg}$ bwt extract/day orally for 60 days.

Diabetes was not induced in the extract control group, but it received $200 \mathrm{mg} / \mathrm{kg}$ bwt of extract. The animal experimental protocols were approved by the ethical committee for animal welfare of Weifang People's hospital, Weifang, People's Republic of China (approval no. YXT134539. All the procedures were performed as per the international ethical guidelines for animal studies [8].

\section{Determination of blood glucose level}

The levels of FBG in all the groups were estimated at zero time (day 0), day 30 and day 60 during the study.

Determination of serum levels of GSH, vitamins $E$ and $C$, and ceruloplasmin

The serum levels of GSH, vitamins $E$ and $C$, and ceruloplasmin were determined in normal and diabetic rats after 60 days of treatment.

\section{Determination of levels of insulin and other plasma proteins}

The levels of insulin, C-peptide, total hemoglobin, $\mathrm{HbA1c}$, and total protein were determined in the serum of normal and diabetic rats.

\section{Lipid profiles, tissue histology and expression of GLUT-4}

The expressions of GLUT-4in soleus muscle and adipose tissue were determined using real-time quantitative polymerase chain reaction (qRTPCR), while histological examination of the pancreas was performed using hematoxylin and eosin $(H$ \& E) staining. The levels of plasma lipids were also determined.

\section{Statistical analysis}

Data are expressed as mean $\pm \mathrm{SD}$, and statistical analysis was performed using SPSS (20.0). Groups were compared using Student $t$ test. Values of $p<0.05$ were considered statistically significant. 


\section{RESULTS}

\section{Oral $\mathrm{LD}_{50}$ of hydro-methanol extract of $P$. cerasus fruits}

Doses of the extract ( $\leq 5000 \mathrm{mg} / \mathrm{kg}$ bwt) did not produce mortality and significant changes in rat behavior. Macroscopic pathological examination of rat organs revealed no visible damage to pancreatic tissue. The $\mathrm{LD}_{50}$ of hydro-methanol extract of $P$. cerasus fruits in the rats was therefore taken to be> $5000 \mathrm{mg} / \mathrm{kg}$ (Table 1).

Table 1: Acute toxicity of hydro-methanol extract of $P$. cerasus fruits

\begin{tabular}{lcccc}
\hline $\begin{array}{l}\text { Dose } \\
\text { (mg/kg } \\
\text { bwt) }\end{array}$ & $\begin{array}{c}\text { Number } \\
\text { of rats }\end{array}$ & Mortality & Survival & $\begin{array}{c}\text { Mortality } \\
\text { ratio }\end{array}$ \\
\hline 10 & 3 & 0 & 3 & $0 / 3$ \\
100 & 3 & 0 & 3 & $0 / 3$ \\
1000 & 3 & 0 & 3 & $0 / 3$ \\
1500 & 1 & 0 & 1 & $0 / 1$ \\
2500 & 1 & 0 & 1 & $0 / 1$ \\
2900 & 1 & 0 & 1 & $0 / 1$ \\
5000 & 1 & 0 & 1 & $0 / 1$ \\
\hline
\end{tabular}

\section{Levels of FBG}

Alloxan-induced DM significantly increased FBG level in the rats. However, after treatment with extract, FBG was significantly reduced in the treatment groups, relative to diabetic control group at different time points $(p<0.05)$. There was no significant difference in FBG between the two treatment groups at day $0(p>0.05)$. However, at day 30 and day 60, FBG levels were significantly reduced in $200 \mathrm{mg} / \mathrm{kg}$ bwt group, relative to the $100 \mathrm{mg} / \mathrm{kg}$ group $(p<0.05)$. These results are shown in Table 2.

Levels of GSH, vitamins $E$ and $C$, and ceruloplasmin

Alloxan-induced DM significantly reduced the plasma levels of $\mathrm{GSH}$, vitamins $\mathrm{E}$ and $\mathrm{C}$, and ceruloplasmin $(p<0.05)$. However, after treatment with extract, the plasma levels of these parameters were significantly and dosedependently increased in the treatment groups, when compared with diabetic control group ( $p<$ 0.05; Table 3).

\section{Insulin and other plasma proteins}

As shown in Table 4, alloxan-induced DM significantly reduced plasma levels of insulin, Cpeptide, total hemoglobin and total protein, and significantly increased HbA1c level $(p<0.05)$. However, after treatment, changes in the levels of these parameters were significantly and dosedependently reversed $(p<0.05)$.

\section{Lipid profiles}

Alloxan-induced DM significantly increased serum TG, LDL-C and HDL-C, and significantly reduced serum TC at the different time points $(p$ $<0.05)$. However, after extract treatment, the levels of TG, LDL-C and HDL-C were significantly reduced, and TC level was significantly elevated time- and dosedependently $(p<0.05$; Figure 1$)$.

Table 2: Effect of extract of $P$. cerasus fruits on plasma glucose levels ( $\mathrm{mmol} / \mathrm{L})$

\begin{tabular}{lccc}
\hline Group & Day 0 & $\begin{array}{c}\text { Duration of treatment } \\
\text { Day 30 }\end{array}$ & Day $\mathbf{6 0}$ \\
\hline Normal control & $3.99 \pm 0.21$ & $4.36 \pm 0.11$ & $4.82 \pm 0.33$ \\
Extract control & $3.68 \pm 0.22$ & $3.99 \pm 0.26$ & $4.66 \pm 0.22$ \\
Diabetic control & $17.1 \pm 1.31^{\mathrm{a}}$ & $19.42 \pm 1.23^{\mathrm{a}}$ & $23.01 \pm 1.98^{\mathrm{a}}$ \\
$100 \mathrm{mg} / \mathrm{kg} \mathrm{bwt} \mathrm{extract}$ & $13.98 \pm 1.14^{\mathrm{ab}}$ & $11.54 \pm 1.44^{\mathrm{ab}}$ & $11.44 \pm 0.76^{\mathrm{ab}}$ \\
$200 \mathrm{mg} / \mathrm{kg} \mathrm{bwt} \mathrm{extract}$ & $13.62 \pm 1.00^{\mathrm{ab}}$ & $10.88 \pm 0.33^{\mathrm{abc}}$ & $8.10 \pm 0.70^{\mathrm{abc}}$ \\
\hline
\end{tabular}

${ }^{a} P<0.05$, when compared to normal control group; ${ }^{b} p<0.05$ when compared to diabetic control group; ${ }^{c} p<0.05$ when compared to $100 \mathrm{mg} / \mathrm{kg}$ bwt group

Table 3: Effect of hydro-methanol extract of $P$. cerasus fruits on levels of plasma GSH, vitamins $\mathrm{E}$ and $\mathrm{C}$, and ceruloplasmin (g/dL)

\begin{tabular}{lcccc}
\hline Group & GSH $\left(\mathbf{x ~ 1 0 ^ { - 1 }}\right)$ & $\begin{array}{c}\text { Vitamin E (x } \\
\left.\mathbf{1 0}^{-\mathbf{2}}\right)\end{array}$ & $\begin{array}{c}\text { Vitamin C (x } \\
\left.\mathbf{1 0}^{-1}\right)\end{array}$ & Ceruloplasmin \\
\hline Normal control & $6.50 \pm 0.30$ & $3.30 \pm 0.10$ & $1.40 \pm 0.20$ & $1.52 \pm 0.10$ \\
Extract control & $6.30 \pm 0.50$ & $3.40 \pm 0.30$ & $1.50 \pm 0.10$ & $1.45 \pm 0.10$ \\
Diabetic control & $3.30 \pm 0.10^{\mathrm{a}}$ & $1.00 \pm 0.20^{\mathrm{a}}$ & $0.44 \pm 0.20^{\mathrm{a}}$ & $0.99 \pm 0.04^{\mathrm{a}}$ \\
$100 \mathrm{mg} / \mathrm{kg}$ bwt extract & $3.90 \pm 0.20^{\mathrm{ab}}$ & $2.60 \pm 0.20^{\mathrm{ab}}$ & $1.00 \pm 0.20^{\mathrm{ab}}$ & $1.34 \pm 0.07^{\mathrm{ab}}$ \\
$200 \mathrm{mg} / \mathrm{kg}$ bwt extract & $6.00 \pm 0.20^{\mathrm{abc}}$ & $3.50 \pm 0.20^{\mathrm{abc}}$ & $1.70 \pm 0.30^{\mathrm{abc}}$ & $1.39 \pm 0.04^{\mathrm{abc}}$ \\
\hline${ }^{\mathrm{a}} P<0.05$ when compared to normal control group; ${ }^{\mathrm{a}} p<0.05$ when compared to diabetic control group; ${ }^{\mathrm{c}} p<0.05$ \\
when compared to $100 \mathrm{mg} / \mathrm{kg}$ bwt group
\end{tabular}


Table 4: Effect of hydro-methanol extract of $P$. cerasus fruits on plasma levels of insulin and other proteins

\begin{tabular}{lccccc}
\hline Group & $\begin{array}{c}\text { Insulin } \\
(\boldsymbol{\mu U} / \mathbf{m l})\end{array}$ & $\begin{array}{c}\text { C-peptide } \\
(\mathbf{n g} / \mathbf{m l})\end{array}$ & $\begin{array}{c}\text { Total } \\
\text { hemoglobin }(\mathbf{g} \%)\end{array}$ & $\begin{array}{c}\text { HbA1c } \\
(\mathbf{m g} / \mathbf{d})\end{array}$ & $\begin{array}{c}\text { Total protein } \\
(\mathbf{g} / \mathbf{d L})\end{array}$ \\
\hline Normal control & $14.11 \pm 1.23$ & $22.46 \pm 1.82$ & $10.30 \pm 0.63$ & $0.45 \pm 0.04$ & $11.44 \pm 0.23$ \\
Extract control & $14.62 \pm 1.33$ & $21.64 \pm 0.99$ & $10.89 \pm 0.65$ & $0.46 \pm 0.21$ & $11.14 \pm 0.35$ \\
Diabetic control & $7.22 \pm 0.62^{\mathrm{a}}$ & $11.99 \pm 1.56^{\mathrm{a}}$ & $6.89 \pm 0.62^{\mathrm{a}}$ & $0.87 \pm 0.01^{\mathrm{a}}$ & $7.52 \pm 0.88^{\mathrm{a}}$ \\
$100 \mathrm{mg} / \mathrm{kg} \mathrm{extract}$ & $9.82 \pm 1.55^{\mathrm{ab}}$ & $16.44 \pm 1.13^{\mathrm{ab}}$ & $9.44 \pm 0.64^{\mathrm{ab}}$ & $0.66 \pm 0.02^{\mathrm{ab}}$ & $8.25 \pm 0.23^{\mathrm{ab}}$ \\
$200 \mathrm{mg} / \mathrm{kg}$ extract & $11.93 \pm 1.43^{\mathrm{abc}}$ & $20.45 \pm 1.97^{\mathrm{abc}}$ & $10.11 \pm 0.43^{\mathrm{abc}}$ & $0.54 \pm 0.01^{\mathrm{abc}}$ & $10 \pm 0.55^{\mathrm{abc}}$ \\
\hline
\end{tabular}

${ }^{\mathrm{a}} P<0.05$, compared to normal control group; ${ }^{\mathrm{b}} p<0.05$ when compared to diabetic control group; ${ }^{\mathrm{c}} p<0.05$, compared to $100 \mathrm{mg} / \mathrm{kg}$ bwt group

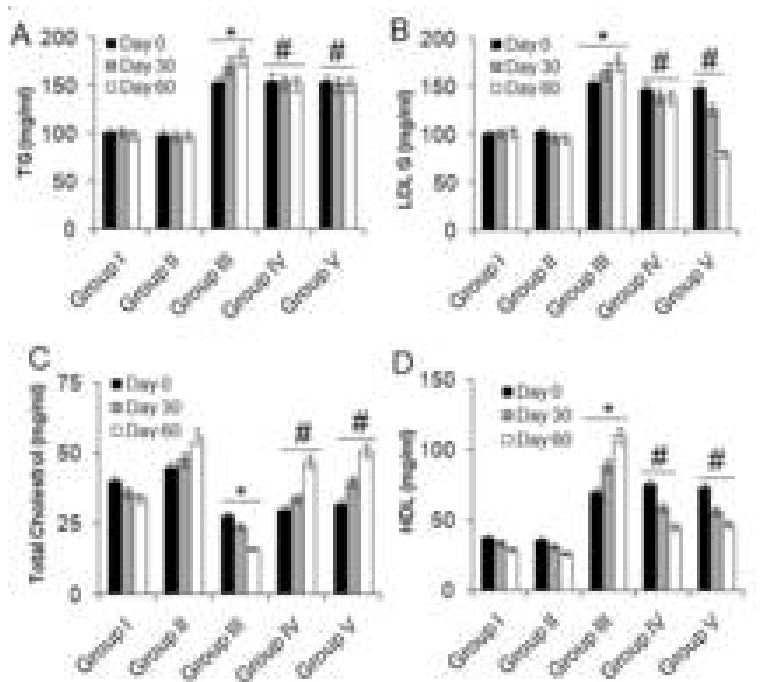

Figure 1: Effect of hydro-methanol extract of $P$. cerasus fruits on lipid profile. A: Triacylglycerols; B: LDL-C; C: TC; D: HDL-C; $p<0.05$, when compared to normal control group; ${ }^{\#} p<0.05$, compared to diabetic control group

\section{Outcome of histological examination}

The results of histological examination showed that the extract alone did not elicit any significant changes in histology of rat pancreas. However, alloxan-induced diabetic rats exhibited pancreatic injury which was characterized by significant reductions in the numbers of islets cells and diameters of pancreatic islets. Islets of Langerhans were severely reduced in diabetic control pancreas, relative to the normal control pancreas. However, the pancreatic injury was markedly mitigated on treatment of the diabetic rats with hydro-methanol extract of $P$. cerasus fruits. Treatment with $100 \mathrm{mg} / \mathrm{kg}$ bwt of the extract induced moderate expansion of islets of Langerhans but the degree of injury was significantly reduced (Figure 2 ).

\section{GLUT-4 mRNAs levels in soleus muscle and adipose tissue}

There were significant reductions in GLUT-4 mRNA levels in adipose tissue and soleus muscle of diabetic control rats, relative to normal control group $(p<0.05)$. However, after treatment of diabetic rats with extract, the level of expression of GLUT-4 mRNA in soleus muscle and adipose tissue was significantly upregulated $(p<0.05$; Figure 3$)$.

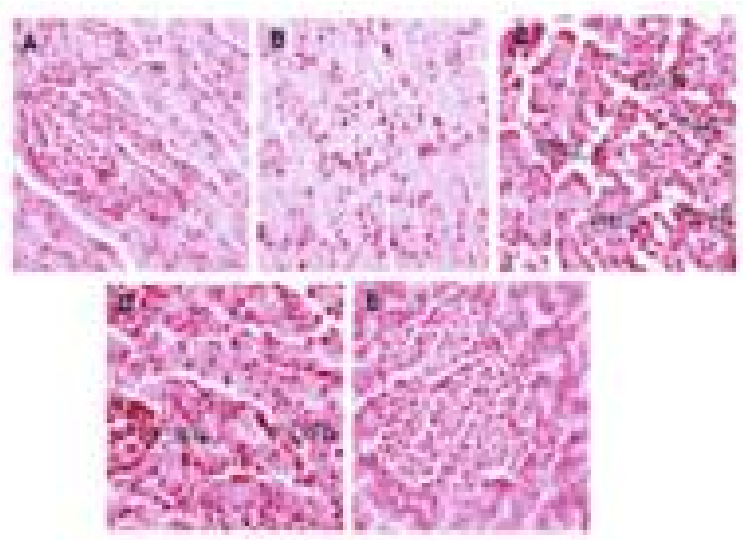

Figure 2: Photomicrographs of sections of rat pancreas. A: Normal control pancreas; B: extract control pancreas; C: diabetic control pancreas; D: 100 $\mathrm{mg} / \mathrm{kg}$ bwt pancreas; E: $200 \mathrm{mg} / \mathrm{kg}$ bwt pancreas

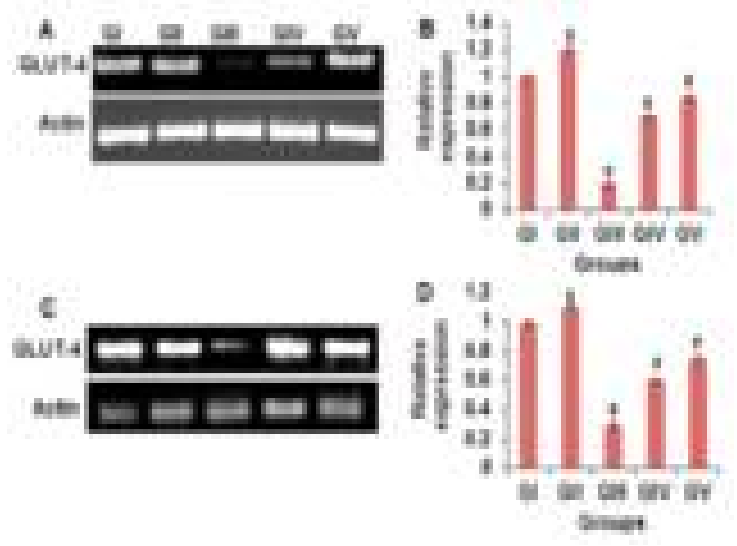

Figure 3: Effect of hydro-methanol extract of $P$. cerasus fruits on the expression of GLUT-4. A: Expression of GLUT-4 in soleus muscle as determined using Western blotting; B: Level of expression of GLUT-4 in soleus muscle as determined using qRTPCR; C: Expression of GLUT-4 in adipose tissue as determined using Western blotting; D: Level of expression of GLUT-4 in adipose tissue as determined using qRT-PCR; $p<0.05$, compared to normal control group; $" p<0.05$, compared to diabetic control group 
Identification of bioactive compounds in hydromethanol extract of $P$. cerasus fruits

As shown in Figures 4 and 5, chlorogenic acid, rutin, diadzin, amygdalin, quercetin, naringenin and gallic acid were identified in hydro-methanol extract $P$. cerasus fruits.

\section{DISCUSSION}

The present study investigated the antidiabetic effect of hydro-methanol extract of $P$. cerasus fruits, and identified its bioactive compounds. The results of acute toxicity study showed that the $L_{50}$ of the extract in rats was greater than $5000 \mathrm{mg} / \mathrm{kg}$ bwt, an indication that the extract is non-toxic. It has been reported that alloxan causes DM by generating reactive oxygen species (ROS) which in turn destroy $\beta$ cells[20].Oxidative stress has been reported to contribute to the pathogenesis of DM [4]. Increased incidence of diabetic complications is due to increased free radical generation or reduced antioxidant defense responses [9].

In this study, alloxan-induced DM significantly reduced plasma levels of insulin, C-peptide, total hemoglobin and total protein, and significantly increased $\mathrm{FBG}$ and $\mathrm{HbA} 1 \mathrm{c}$ levels.

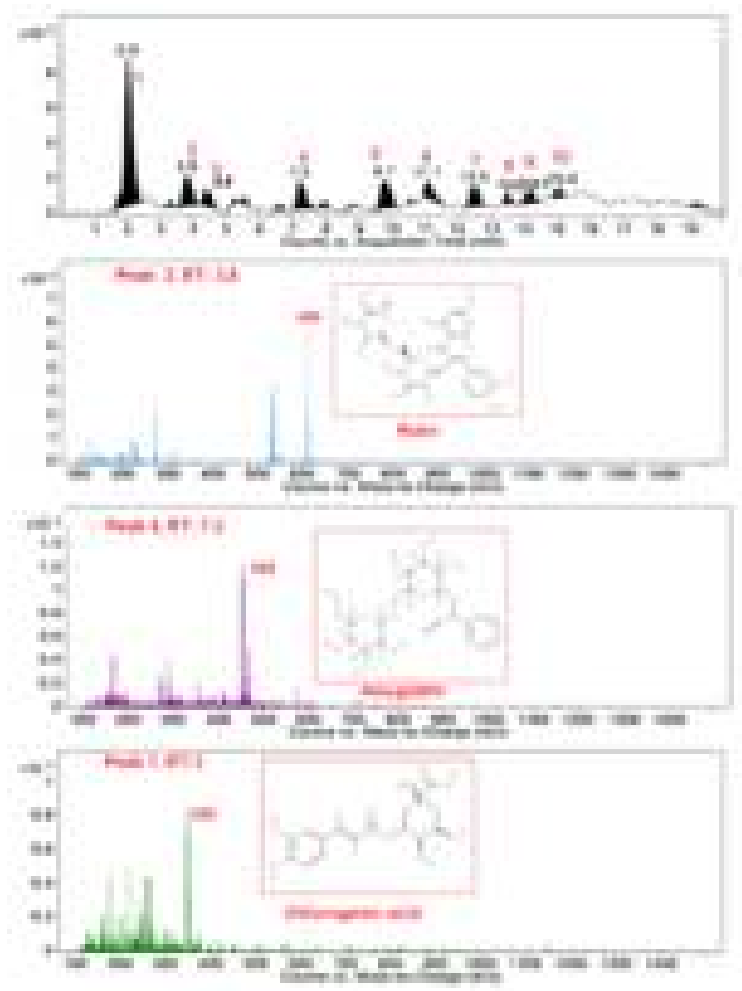

Figure 4: $\mathrm{ESI}(+)$ LC/MS total-ion current (TIC) traces of compounds in hydro-methanol extract of $P$. cerasus fruits
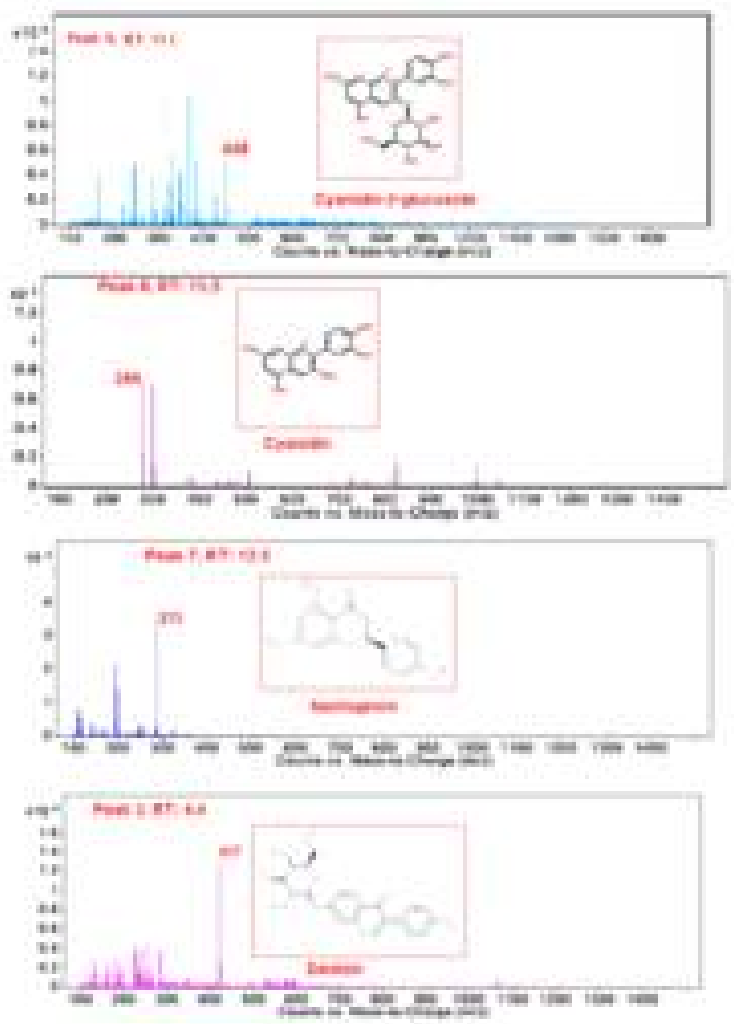

Figure 5: Mass chromatograms of cyanidin-3glucoside, cyanidin, naringenin and daidzin

However, after treatment with hydro-methanol extract of $P$. cerasus fruits, changes in the levels of these parameters were significantly dosedependently reversed. The extract also potentiated the non-enzyme antioxidants. It is likely that the extract inhibited lipid peroxidation and alloxan-induced oxidative stress in the diabetic rats. The increase in the level of insulin after treatment with extract may also be attributed to the stimulatory effect of the extract on the pancreatic $\beta$-cells which survived after induction of DM. Extract-promoted restoration of pancreatic $\beta$-cells may also be responsible for the enhanced insulin secretion.

The generation of free radicals in situations of severe oxidative stress leads to modification of cellular proteins [10]. Studies have shown that the level of plasma total protein is reduced in DM [11].

In this study, alloxan-induced DM significantly increased the levels of TG, LDL-C and HDL-C, and significantly reduced the level of TC at the different time points. However, after treatment with extract, the levels of TG, LDL-C and HDL-C were significantly reduced, while TC level was significantly elevated time- and dosedependently. Increased level of TG in the diabetic rats suggests a condition of hypertriglyceridemia which may be due to

Trop J Pharm Res, March 2019; 18(3):601 
overproduction of very low-density lipoprotein (VLDL) cholesterol by the liver. These results suggest that hydro-methanol extract of $P$. cerasus fruits may normalized altered lipid profiles in diabetic rats.

In this study, the islets of Langerhans in the alloxan-induced rat pancreas were necrotic and damaged. However, treatment with the extract remarkably restored these histopathological changes and induced a distinct granulated and protective effect on pancreatic $\beta$-cells.

Studies have shown that DM leads to marked reduction in GLUT-4 expression [5,6]. In this study, there were significant reductions in GLUT4 mRNA levels in adipose tissue and soleus muscle of diabetic control rats, relative to normal control group. However, after treatment of diabetic rats with extract, the level of expression of GLUT-4 mRNA in soleus muscle and adipose tissue was significantly upregulated.

Results from LC-MS revealed the presence of chlorogenic acid, rutin, diadzin, amygdalin, quercetin, naringenin and gallic acid in the extract of $P$. cerasus fruits, an indication that this extract may be a rich source of important flavonoids and phenolic compounds. Studies have shown that phenolic compounds function as potent antioxidants, and phytochemicals such as rutin, naringenin, and quercetin exert beneficial effect on DM $[7,12,13]$. Thus, the antidiabetic effect of this extract could be attributed to its active phytochemical constituents such as flavonoids and phenolic compounds.

\section{CONCLUSION}

The results obtained in this study show that the hydro-methanol extract of $P$. cerasus fruits is a rich source of important flavonoids and phenolic compounds which synergistically contribute to its antidiabetic effect.

\section{DECLARATIONS}

\section{Conflict of Interest}

No conflict of interest associated with this work.

\section{Contribution of Authors}

We declare that this work was done by the authors named in this article and all liabilities pertaining to claims relating to the content of this article will be borne by the authors. This study was performed by Gong Xiao. The manuscript was written by Xiangcheng Xiao. The whole study was supervised by Xiangcheng Xiao.

\section{REFERENCES}

1. Bonerz D, Würth $K$, Dietrich $H$, Will $F$. Analytical characterization and the impact of ageing on anthocyanin composition and degradation in juices from five sour cherry cultivars. Euro Food Res Technol 2007; 224: 355-364.

2. Cásedas G, Les $F$, Gómez-Serranillos MP, Smith $C$, López V. Bioactive and functional properties of sour cherry juice (Prunus cerasus). Food Func 2016; 7: 4675-4682.

3. Lamport DJ, Saunders C, Butler LT, Spencer JP. Fruits, vegetables, $100 \%$ juices, and cognitive function. NutRev 2014; 72: 774-789.

4. Baynes JW, Thorpe SR. Role of oxidative stress in diabetic complications: a new perspective on an old paradigm. Diabetes 1999; 48: 1-9.

5. Berger J, Biswas C, Vicario PP, Strout HV, Saperstein R, Pilch PF. Decreased expression of the insulinresponsive glucose transporter in diabetes and fasting. Nature 1989; 340: 70-75

6. Sivitz WI, DeSautel SL, Kayano T, Bell GI, Pessin JE. Regulation of glucose transporter messenger RNA in insulin-deficient states. Nature 1989; 340: 72-76.

7. Baba SA, Malik AH, Wani ZA, Mohiuddin T, Shah Z, Abbas N, Ashraf N. Phytochemical analysis and antioxidant activity of different tissue types of Crocus sativus and oxidative stress alleviating potential of saffron extract in plants, bacteria, and yeast. S Afr J Bot 2015; 99: 80-87.

8. Kilkenny C, Browne WJ, Cuthill IC, Emerson M, Altman $D G$. Improving bioscience research reporting: the ARRIVE guidelines for reporting animal research. PLOS Biol 2010; 8: 1-7.

9. Jakus $V$. The role of free radicals, oxidative stress and antioxidant systems in diabetic vascular disease. Bratislavske lekarske listy 2000; 101: 541-551.

10. Gumieniczek $A$. Effects of repaglinide on oxidative stress in tissues of diabetic rabbits. Diabetes Res Clinl Prac 2005; 68(2): 89-95.

11. Mahboob M, Rahman MF, Grover $P$. Serum lipid peroxidation and antioxidant enzyme levels in male and female diabetic patients. Singapore Med J 2005; 46(7): 322-324.

12. Coskun O, Kanter M, Korkmaz A, Oter S. Quercetin, a flavonoid antioxidant, prevents and protects streptozotocin-induced oxidative stress and $\beta$-cell damage in rat pancreas. Pharmacol Res 2005; 51: 117123. 